\title{
Modelling the long-term water balance of a pit lake with recreational end uses
}

\author{
AM Carlino Golder Associates Pty Ltd, Australia \\ CD McCullough Mine Lakes Consulting, Australia
}

\begin{abstract}
Pit lakes can be used for recreation when water quality is suitable. However, when lake levels are too low, pit lakes may pose access and slope instability risks to recreational users. An essential tool to assist in managing these risks is a good understanding of the lake water balance.

A groundwater model was developed to investigate whether impending cessation of mine water discharge into historic Lake Stockton (Collie, Western Australia) would result in reduced recreational values, e.g. for water skiing. Currently, the lake water level is kept reasonably constantly elevated with the addition of mine water from nearby dewatering at Ewington mine (Lanco, Griffin Coal) operations.

Lake Stockton has a maximum depth of $30 \mathrm{~m}$ and groundwater flows through historic underground mine workings contribute largely to the overall pit inflow. A steady state groundwater model was used to emulate the regional groundwater flow in the Collie Coal Basin. The model gave estimates of groundwater fluxes and predictions of the future lake water level if mine discharges were to stop.

Transient simulations forecast a 3.6-3.9 m decline in the long-term lake water level without mine water input, with non-mine groundwater inflow rates increasing from commensurately steeper hydraulic gradient from a declining lake level in steady state. As a result, although the water level of Lake Stockton would still be suitable for public recreation, the decline in the water level would expose steep pit walls and reduce the regulation recreational area by $17 \%$. Consequently, rehabilitation planning for this lake should account for safe access if recreation is to be permitted when the predicted decline in water levels takes place.
\end{abstract}

The study highlights the critical importance of understanding the hydrogeological setting and the controls over lake levels in-pit voids for maintenance of recreational end use values.

Keywords: pit lake, recreation, water balance, numerical modelling

\section{Introduction}

\subsection{Pit lakes}

Open cut mining has become a widespread practice in modern mining operations. Pit lakes can form when open cut mining dewatering operations are discontinued or abandoned, and groundwater water levels recover (Castro \& Moore 2000). Early research was driven by the need for closed open cut mines to comply with regulatory mine closure water quality guidelines (Castendyk et al. 2015). As pit lakes are permanent landscape features, it is important to assess potential risks long after mine closure (McCullough \& Lund 2006).

Commander et al. (1994) grouped pit lakes into three broad categories regarding their local hydrogeological interaction:

1. Groundwater sink: the rate of evaporation exceeds groundwater inflow with the absence of groundwater outflow resulting in salinisation over time. 
2. Groundwater through-flow: the lake acts as a flow-through system with the rate of groundwater inflow exceeding the rate of evaporation and some increase in salinity as water moves from entry to exit.

3. Groundwater recharge: the rate of groundwater inflow exceeds evaporation, with the water levels rapidly recovering to pre-mining levels (high rainfall environments).

\subsection{Recreational use}

Pit lakes are used for recreation globally. In recent years, open cut mines have deliberately rehabilitated pit lakes for recreation, e.g. Schultze et al. (2013). Despite this, recreation and tourism are believed to have the highest social risk compared to other pit lake end uses due to increased human traffic (Hinwood et al. 2012; McCullough et al. 2018). Water quality is usually a concern for recreational use of pit lakes whereas the lake's physical characteristics (i.e. water level or slope) and its impacts to health and safety are often disregarded. When lake water levels become too low, boating, water skiing, and swimming become a risk. Limited research has been undertaken on the recreational use of lakes and no prior studies have focused on a water balance to determine the suitability of water levels for recreation. This is because pit lakes reviews are often carried out on a case-to-case basis by consultancies for environmental or economic requirements. With pit lakes being utilised more frequently by the public for recreation, there is a growing need to understand a pit lakes water balance and groundwater-lake interactions.

\subsection{Pit lake modelling}

Water balances can provide an improved understanding of factors that control a pit lake's water level and a means of forecasting future system behaviour. A common approach to understand a pit lake's water balance is with a pit lake model that considers the inputs and outputs of a lake system (Figure 1). Once validated, these models can assist with lake management decisions to decide acceptable post-closure uses and minimise the associated potential liabilities (Castendyk et al. 2015). Water balance models for pit lakes can be solved with analytical and numerical approaches. Such models often aim to estimate the time in which a pit will fill to a steady state level or to estimate the volume of specific lake inputs and outputs for further pit lake hydrodynamic and geochemical modelling (Castendyk et al. 2015).

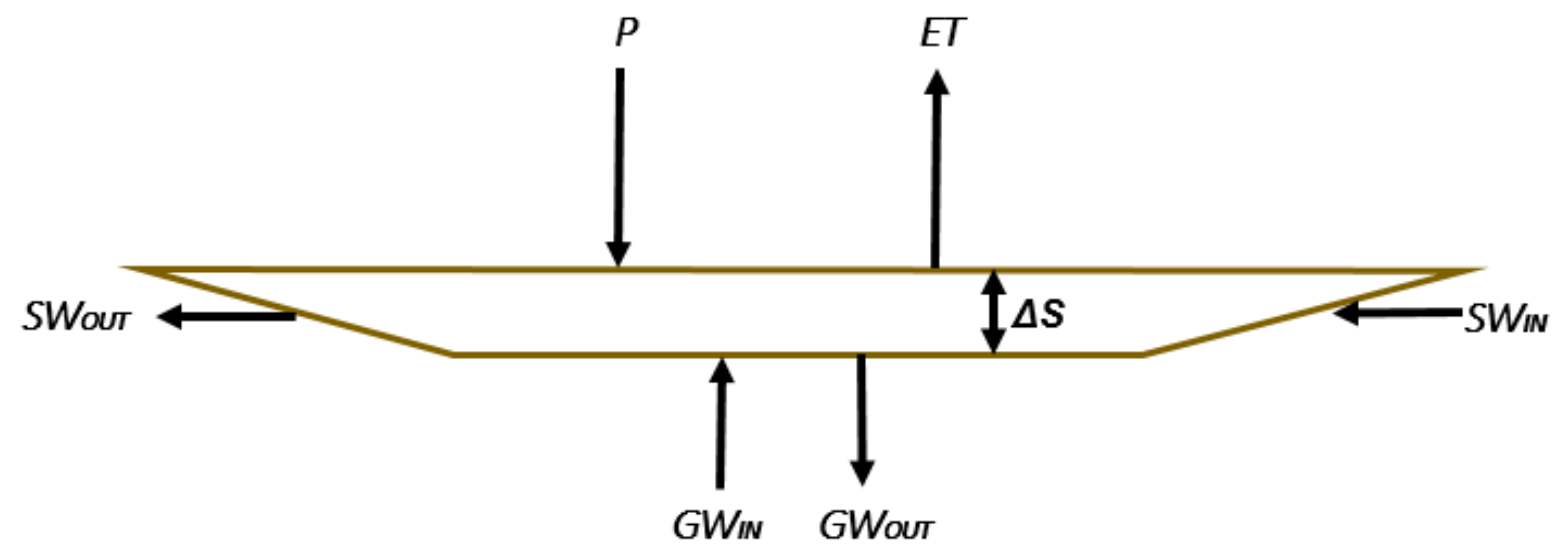

Figure 1 Cross-sectional view of volumetric water balance components for open water systems (after Council 1997). $\mathrm{P}=$ precipitation; $\mathrm{ET}=$ evaporation; $S W_{\mathrm{IN}}=$ surface water inflow; $S W_{\mathrm{OUT}}=$ surface water outflow; $\mathrm{GW}_{\mathrm{IN}}=$ groundwater discharge; $\mathrm{GW}_{\mathrm{OUT}}=$ groundwater recharge; $\Delta \mathrm{S}=$ change in storage

Dynamic probabilistic models are effective at predicting lake data temporally when system inputs and outputs are known in significant detail (Balistrieri et al. 2006), but they are limited in their accuracy when the groundwater component is not well understood or well quantified. In regions where groundwater is thought to be the main source of pit lake recharge or discharge, estimating a reasonable groundwater inflow value is critical for a representative water balance (Hanna et al. 1994; Niccoli 2009; McCullough et al. 2013). 
Groundwater inflow is often overlooked or estimated in-pit lake water balances, resulting in significant uncertainties in model predictions.

Incorporating lakes in groundwater models is a sophisticated approach used to investigate regional groundwater-lake interactions. Notably, the accuracy of these models has improved with advancement of modelling tools and increased processing power (Hunt et al. 2003). Early simulations employed fixed constant head boundaries for lakes (Hunt et al. 1998), although this approach is limited as it cannot simulate lake stage fluctuations. Another approach is to represent lakes as high conductivity features (Lee 1996; Anderson et al. 2002). However, this method does not account for other surface water flows. Lake packages for groundwater modelling software MODFLOW have been developed to solve for the lake stage and calculate a lake budget based on the lake stage (Merrit \& Konikow 2000). These packages allow for groundwater flow to be integrated with the lake water balance components and eliminate the additional effort of setting up two separate models for groundwater and pit lake modelling.

\subsection{Study site}

Lake Stockton occupies a historic open pit coal mine located in the Collie Basin in the southwest of Western Australia, approximately $200 \mathrm{~km}$ south-southeast of Perth (Figure 2). Stockton underground mining operations commenced in 1927 and progressed with open cut mining in 1943 to increase coal production. Stockton was the first underground mine to be re-mined using the open cut method, with the open pit providing easy access to underground operations. The Stockton mine was abandoned in 1957 by Amalgamated Collieries, with no attempt at rehabilitation (Stedman 1988). The pit water level has since recovered, creating a lake that is primarily used for boating and water skiing by locals (Hinwood et al. 2012; Lund et al. 2012). Lake Stockton is currently managed by the Western Australian Department of Biodiversity, Conservation and Attractions' Parks and Wildlife Service.

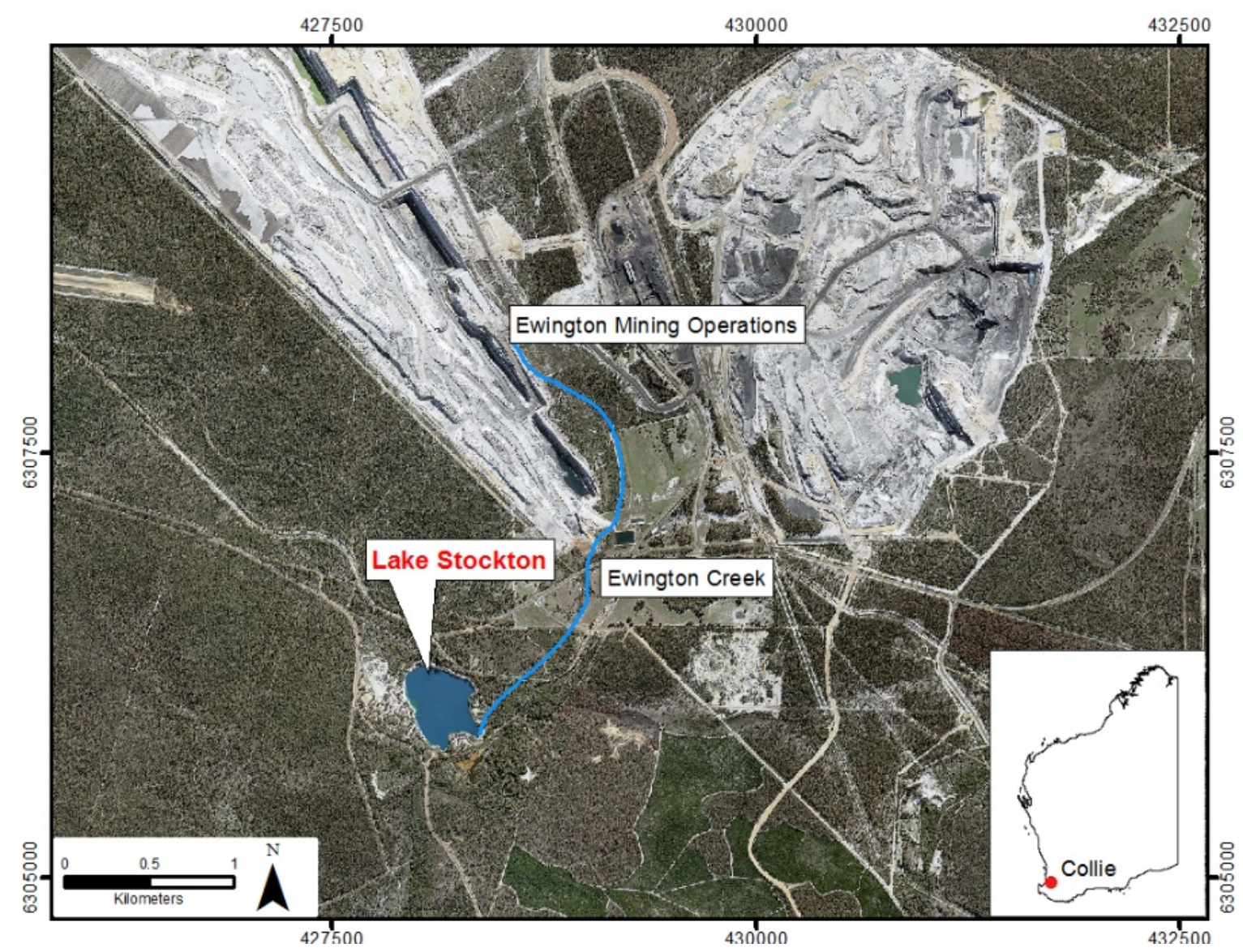

Figure 2 Lake Stockton location map [Coordinate system: GDA 1994 MGA Zone 50] 
Other mining activities and subsequent discharge to Lake Stockton commenced in 1996 with development of the Ewington II mine. Circumneutral water from Ewington mine dewatering operations (northeast of Lake Stockton) enters Lake Stockton from the east via Ewington Creek. Cessation of discharge from excess water from dewatering at Ewington mining operations are expected to result in lower water levels such that the lake is not suitable for safe recreational activities. Measured lake levels provided by Griffin Coal have declined in recent years from an already reducing rate of discharge, necessitating warning signage to advise visitors of exposed steep banks (Figure 3).

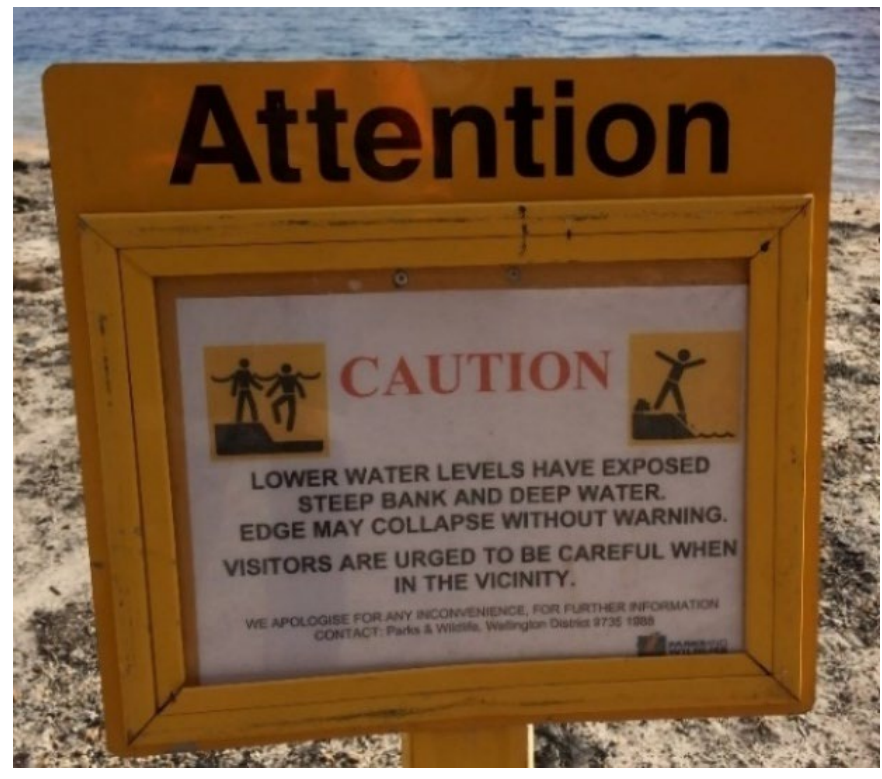

Figure 3 Warning sign at the Lake Stockton carpark taken looking north on 21 June 2017

Figure 4 shows bathymetry data for Lake Stockton collected by McCullough et al. (2011). Physical dimensions of Lake Stockton are outlined in Table 1. Original mine plans (open cut and underground) were not available for review.

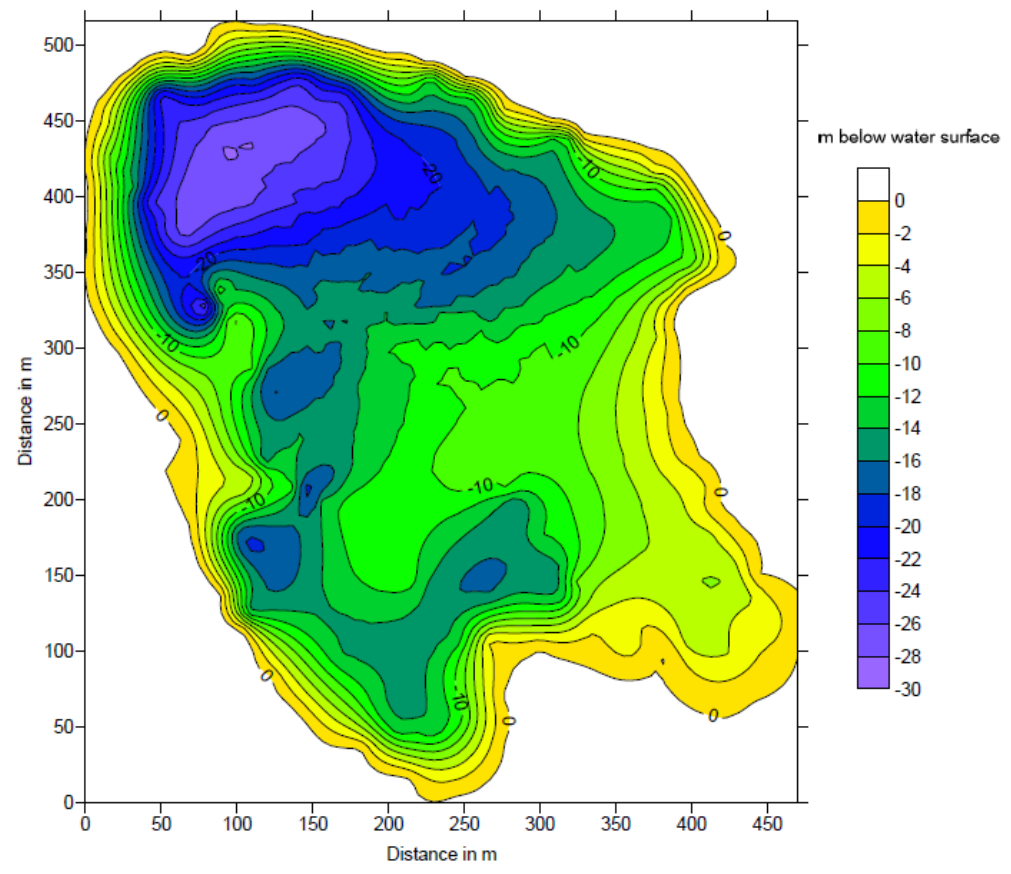

Figure 4 Bathymetry of Lake Stockton (McCullough et al. 2011) 
Table 1 Physical characteristics of Lake Stockton

\begin{tabular}{ll}
\hline Parameter & Value \\
\hline Easting and northing (universal transverse mercator) & $428130 \mathrm{mE}, 6306040 \mathrm{mN}$ \\
Area & $140,720 \mathrm{~m}^{2}$ \\
Perimeter & $1660 \mathrm{~m}$ \\
Elevation & $200 \mathrm{~m} \mathrm{AHD}$ \\
Maximum depth & $30 \mathrm{~m}$ \\
Radius (average) & $214 \mathrm{~m}$ \\
Overflow/culvert height & $195 \mathrm{~m} \mathrm{AHD}$ \\
\hline AHD = Australian height datum &
\end{tabular}

Multiple geochemical studies have been undertaken on Lake Stockton (Lund et al. 2000; McCullough et al. 2009; Müller et al. 2010; Lund et al. 2012). The only water balance work previously undertaken was by Müller et al. (2010) to determine what effects the proposed regional groundwater abstraction regime would have on pit lake water levels. Using a previously constructed regional FEFLOW model, an inflow rate of $0.0012 \mathrm{~m}^{3} / \mathrm{s}(0.1 \mathrm{ML} / \mathrm{d})$ was estimated into Lake Stockton using a constant head condition to represent the average lake level. Model results could be improved by incorporating new lake boundary conditions in the groundwater model with a coupled lake-groundwater model.

\subsection{Hydrogeological setting}

The Stockton mine produced coal from the Muja Formation of the Collie Basin; a remnant of Permian age sedimentary rocks set in Archean metamorphic basement rocks of low permeability. The Collie Basin comprises two lobe shaped sub-basins; the Premier sub-basin to the east and Cardiff sub-basin to the west (Moncrieff 1993). Stockton Ridge - a fault-controlled basement high divides the sub-basins (Wilson 1990). The Stockton Ridge influences groundwater flow to Lake Stockton (Zhang et al. 2007), although the northern extent of this basement ridge is unknown.

The Collie Basin is a complex, anisotropic, multi-layered aquifer system with seven distinct regional aquifers (Moncrieff 1993). With the exception of the Nakina Formation and surficial sediments, the geological units form individual sandstone aquifers separated by extensive coal seams or thick siltstone layers that act as aquitards, although hydraulic connection could occur between them along faults (Hammond \& Boyd 1988). With the exception of superficial sediments, the upper two formations (the Nakina aquifer and Muja aquifer) form individual sandstone aquifers that intercept Lake Stockton. The regional groundwater flow system is unconfined near the surface and confined at depth by coal seams, with the Nakina aquifer in direct hydraulic connection with the underlying Muja aquifer.

\section{Methodology}

\subsection{Model design}

\subsubsection{Modelling approach}

A regional groundwater model was developed in MODFLOW with Groundwater Vistas (Environmental Simulations Incorporated 2000) to simulate three-dimensional steady state flow conditions between groundwater and Lake Stockton. The objective of the model was to simulate changes in groundwater fluxes as the dewatering discharge from Ewington ceases, to allow the water balance changes to estimate lake level changes. Once the regional groundwater flow was set up and calibrated, a water balance was undertaken to predict the future water level of Lake Stockton with the cessation of operational discharge. In order to 
capture more of the complexity of the Collie Basin hydrogeology and groundwater-surface water interaction than is possible in a simplistic analytical model, a numerical model was used. However, the configuration of the numerical model was kept simple to be consistent with the limited data available for calibration and verification. MODFLOW was chosen as the preferred modelling package as it was suitable for purpose and for the application of the lake package (LAK3). The LAK3 package by Merrit \& Konikow (2000) was used within MODFLOW to simulate groundwater-lake interactions of Lake Stockton. The package allowed for the inclusion of surface water flows, simulating both steady state and transient problems, and was able to calculate changes in lake level by performing a water balance calculation at each time step (Hunt et al. 2003).

\subsubsection{Model area, grid and layers}

The model covers an area of $47.5 \mathrm{~km}^{2}$, extending approximately $9 \mathrm{~km}$ in the regional flow direction (southwest to northeast direction). It is centered on Lake Stockton and has a regional grid cell size of $100 \times 100 \mathrm{~m}$ with Lake Stockton refined to a cell size of $25 \times 25 \mathrm{~m}$. The model extent was selected as a reasonable spatial distance to avoid boundary conditions influencing model results and to incorporate the total area that could contribute to groundwater inflow into the lake.

Constant head boundaries were placed along groundwater contours (southern constant head boundary) or were based on hydraulic heads in nearby monitoring wells (northern constant head boundary). No-flow boundaries were placed perpendicular to the regional groundwater flow of the basin (Figure 5). The deeper aquifers were assumed to not have any bearing on the Stockton water balance and have been excluded from the model. Current mine dewatering at Ewington operations were assumed to have limited influence on the current potentiometric surface based on the distance from Lake Stockton.

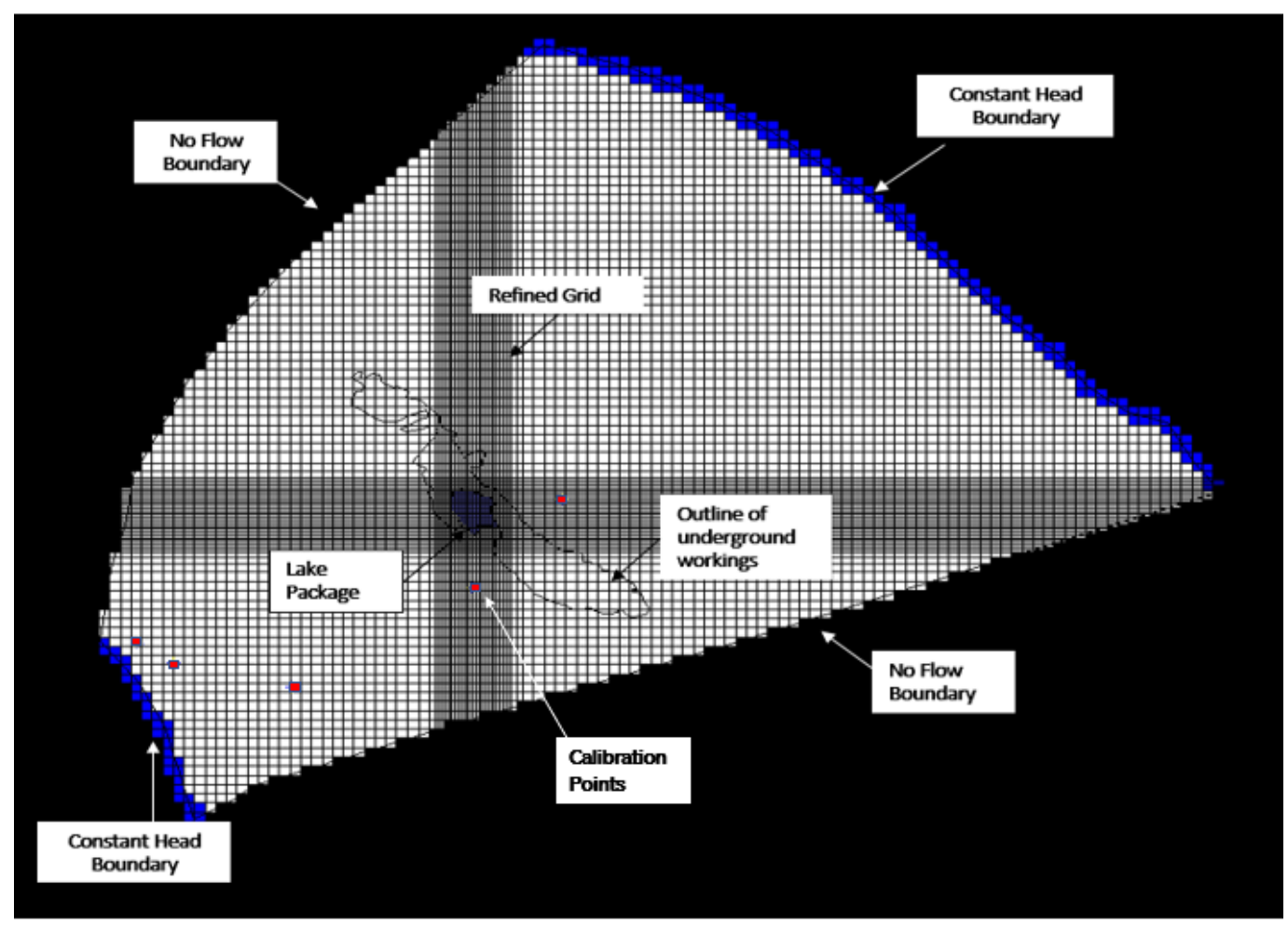

Figure 5 Model grid and site features of the model (the domain is orientation where up is north)

The top surface of the model was defined by site topographic contours ( $5 \mathrm{~m}$ contour spacing) and the model base was set to $0 \mathrm{~m}$ AHD (approximately $200 \mathrm{~m}$ below the elevation of Lake Stockton). To numerically represent the stratigraphy, the model was divided into three vertical layers based on the stratigraphic units presented in Le Blanc Smith (1993). The Nakina and Muja aquifers were represented by one and two horizontal layers, respectively. The topographic elevation (sourced from Landgate) was used for the top of 
the Nakina aquifer layer. The upper layer of the Muja aquifer was used to represent the higher conductivity assumed to be caused by the presence of extensive underground workings.

\subsubsection{Hydraulic properties}

Numerical layers and post-calibrated hydraulic parameters used in the model are outlined in Table 2. Model parameters were initially selected from Varma (2002) who conducted widespread hydraulic testing in the basin, and then were varied by a minor degree from the initial values during the calibration process. To successfully calibrate the model, a zone of lower hydraulic conductivity $(0.20 \mathrm{~m} / \mathrm{d})$ was later added to the right of Lake Stockton in Layer 1 to account for the steeper gradient regarded as caused by the presence of the low conductivity Stockton Ridge.

Table 2 Numerical model layers and hydraulic parameters (post-calibration). $\mathrm{Kx}=$ horizontal hydraulic conductivity, $\mathrm{Kz}=$ vertical hydraulic conductivity, Ss = specific storage, and Sy = specific yield

\begin{tabular}{llllllllll}
\hline $\begin{array}{l}\text { Model } \\
\text { layer }\end{array}$ & Aquifer & Type & $\begin{array}{l}\text { Elevation } \\
\text { range } \\
(\mathbf{m} \text { AHD) }\end{array}$ & Thickness & $\begin{array}{l}\mathrm{Kx} \\
(\mathrm{m} / \mathrm{d})\end{array}$ & $\begin{array}{l}\mathrm{Ky} \\
(\mathrm{m} / \mathrm{d})\end{array}$ & $\begin{array}{l}\mathrm{Kz} \\
(\mathrm{m} / \mathrm{d})\end{array}$ & Ss & Sy \\
\hline 1 & Nakina & Unconfined & $\begin{array}{l}\text { Ground } \\
\text { surface-170 }\end{array}$ & Variable & 0.6 & 0.6 & 0.01 & $10^{-3}$ & 0.15 \\
2 & Muja & Unconfined & $170-165$ & 5 & 2 & 2 & 0.001 & $10^{-4}$ & 0.1 \\
3 & Muja & Unconfined & $176-0$ & 176 & 2 & 2 & 0.001 & $10^{-4}$ & 0.1 \\
\hline
\end{tabular}

A median value of $10 \%$ annual rainfall was used for steady state recharge and was assumed to be homogeneous over the model area, based on an estimate from Varma (2002). Recharge was varied during model calibration and found to give best results with $8 \%$ recharge $(74.8 \mathrm{~mm} /$ annum).

Long-term (1901 to 2016) average annual rainfall from the Collie Station (ID 009628), $7.4 \mathrm{~km}$ from Lake Stockton (Australian Bureau of Meteorology website), was used in the model (929.6 mm). Long-term annual Class A pan evaporation data at Wilga station (35 km from Lake Stockton) was 1,360 mm/year for 1952 to 2015 (DSITIA SILO climate data website). Annual evaporation exceeds annual rainfall, with evaporation rates exceeding rainfall from October to April. A pan conversion coefficient of 0.850 for Donnybrook was established by Luke et al. (1987) who derived annual dam pan evaporation coefficients for dams in Western Australia. This approach was proven successful for small storages (less than $4 \mathrm{~m}$ ) and not necessarily for larger pit lakes, although, it is assumed to be a reasonable estimation of lake evaporation for this study. Monthly averages for rainfall and evaporation were used in the transient simulation to simulate seasonal variations.

\subsubsection{Lake Stockton}

An initial lake stage of $194.4 \mathrm{~m}$ AHD was used based on the average lake stage between December 2016 and June 2017 from lake measurements provided by Griffin Coal. The package also incorporates lakebed sediments that may hinder lake-aquifer connectivity, where an assumed thickness of $0.2 \mathrm{~m}$ and a conductivity of $0.01 \mathrm{~m} / \mathrm{d}$ for silty material was assumed (Fetter 1994). Since Lake Stockton has been forming since the $1950 \mathrm{~s}$, it is reasonable to assume fine-grained sediments have accumulated at the base of the lake, reducing the lake-aquifer hydraulic connection. A discharge rate of $100 \mathrm{~m}^{3} / \mathrm{d}$ was input into the lake package to simulate current conditions based on the average discharge rate for 2017 from data provided by Griffin Coal. Catchment runoff into the lake was considered negligible for the purposes of this study and has been excluded.

Historical underground mine workings connect to Lake Stockton in the northwest to southeast orientation. The approximate extent of underground workings from Le Blanc Smith (1993) displayed in Figure 6 was used as a guide for the model. The backfilled workings were represented in the model with increased hydraulic conductivity in the upper Muja Formation (Layer 2). As no data is available on the conductivity of these mine 
shafts and drives, a conservative value of $2.5 \mathrm{~m} / \mathrm{d}$ was assumed, $0.5 \mathrm{~m} / \mathrm{d}$ higher than the surrounding Muja aquifer horizontal hydraulic conductivity. A similar approach was undertaken by Zhang et al. (2007) in the regional Collie model to account for the widespread distribution of underground mines in the upper Muja aquifer, although, since their model included multiple underground mines, they placed an overall hydraulic conductivity for the layer instead of a specified zone.

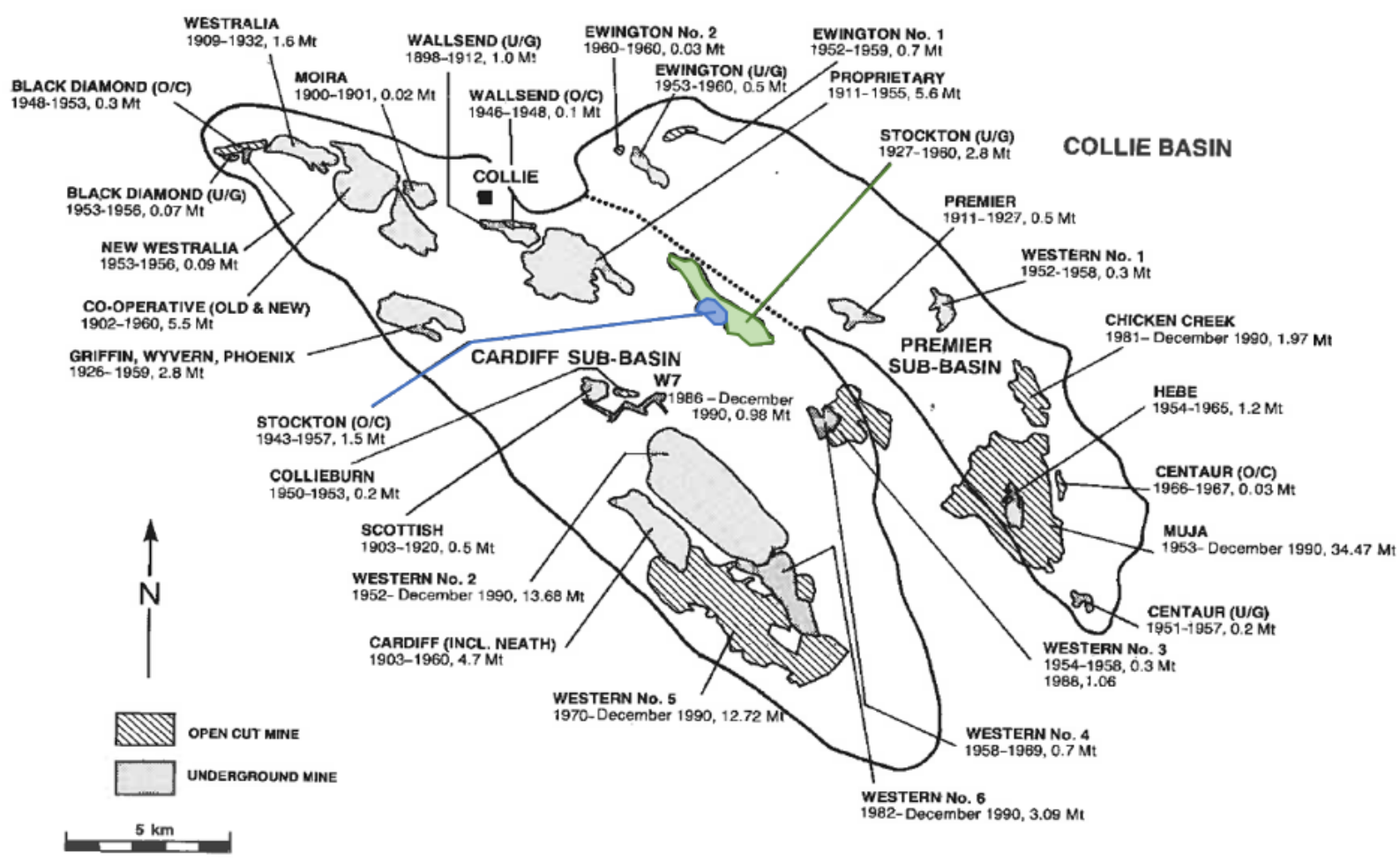

Figure 6 Map of historical mine workings in the Collie Basin (Le Blanc Smith 1993)

\subsection{Model calibration}

Calibration of the steady state model was achieved through a trial-and-error process, by the refinement of hydraulic conductivities and recharge rates until the simulated hydraulic heads compared reasonably well with observed groundwater elevations. Calibration targets for the model comprised of average water levels between 2015 and 2017 from five regional monitoring wells within the model boundary (Figure 5) that intercept the unconfined aquifer. Limited calibration targets were available as many monitoring bores in the area intercept the confined system. Calibration focused on creating the best fit with data for monitoring upstream and downstream of Lake Stockton. There is a limited number of shallow monitoring wells in the Collie Basin, with most wells screened into deep, confined aquifers.

Modelled contours deviate from the generated contours generated in the north and east of the model, indicating further calibration targets in these areas would assist in refining model results (Figure 7). Measured heads plotted against simulated heads has an $r^{2}$ of 0.99 , a root mean square (RMS) error of $0.51 \mathrm{~m}$ and \%RMS of 2.2 . 


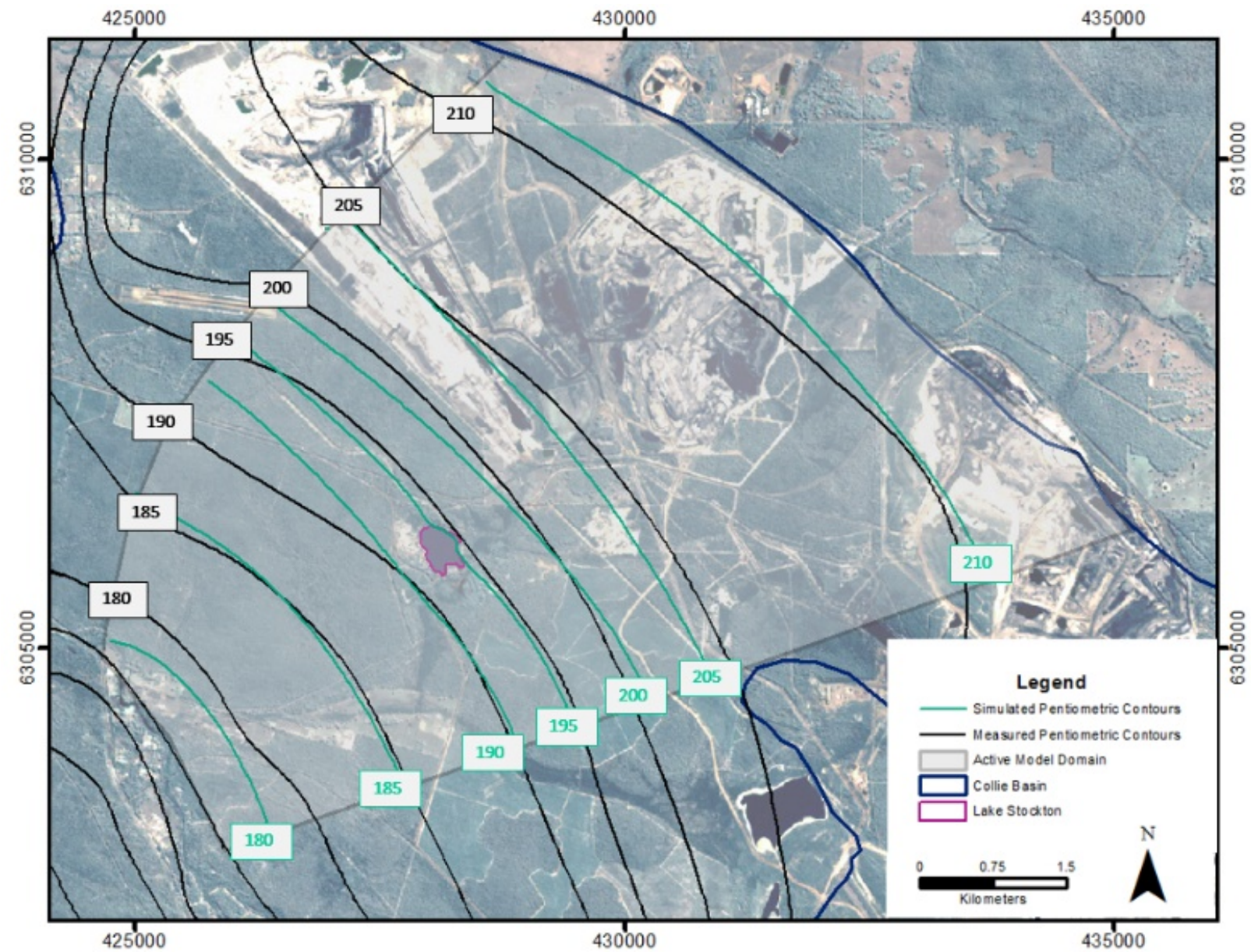

Figure 7 Comparison of measured (February 2017) and simulated potentiometric surfaces in $\mathrm{m}$ AHD [Coordinate system GDA 1994 MGA Zone 50; Aerial Imagery @ Metro Smartsheet 2009]

Calibration quality is considered acceptable for the purposes of this study, even though it was limited by the number of calibration targets, in particular the east of Lake Stockton.

\section{$3 \quad$ Results}

\subsection{Groundwater fluxes}

The system was first simulated under steady state conditions (Figure 8), with the hydraulic gradient flowing from east to west. Groundwater fluxes into and out of Lake Stockton were estimated with the calibrated, steady state groundwater flow model. The model indicated groundwater inflow and outflow rates of $65 \mathrm{~m}^{3} /$ day $(0.75 \mathrm{~L} / \mathrm{s})$ (Table 3). The variation in each layer is likely due to variable hydraulic properties in each layer, with greater inflow into Layer 2 due to the presence of underground mine workings modelled to the east of the lake. The prediction was validated with Darcy's Law, estimating $20 \mathrm{~m}^{3} / \mathrm{d}$ and correlated well with Müller et al. (2010) result of $100 \mathrm{~m}^{3} / \mathrm{d}$. 


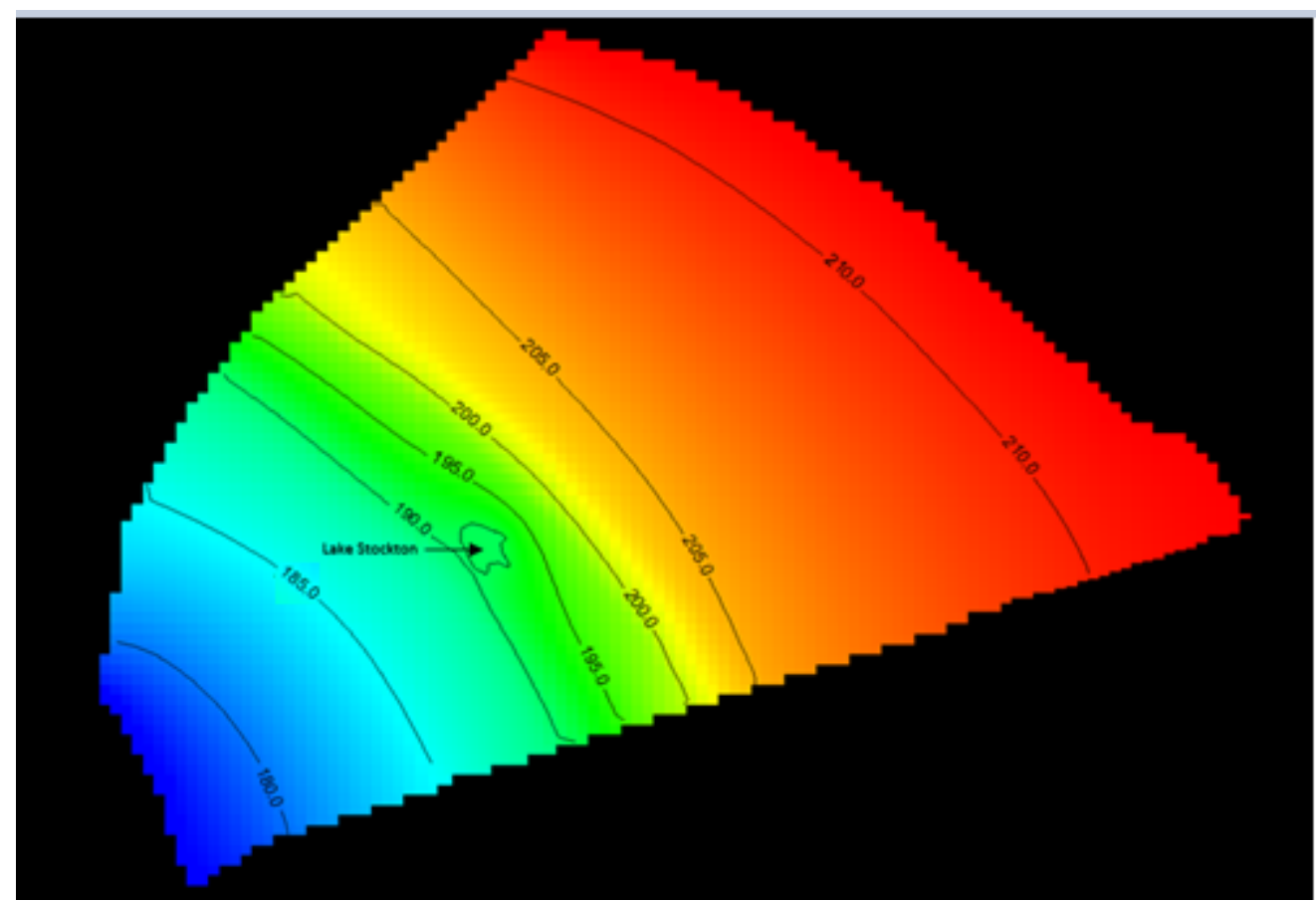

Figure 8 Simulated potentiometric contours (m AHD) for Lake Stockton under steady state conditions

Table 3 Groundwater fluxes estimated within the model for each lake layer

\begin{tabular}{lll}
\hline Lake layer & Inflow $\left(\mathrm{m}^{3} / \mathrm{d}\right)$ & Outflow $\left(\mathrm{m}^{3} / \mathrm{d}\right)$ \\
\hline Layer 1 (Nakina aquifer) & 53.4 & 55.2 \\
Layer 2 (Upper Muja aquifer) & 11.9 & 10.1 \\
Total & $\mathbf{6 5}$ & $\mathbf{6 5}$ \\
\hline
\end{tabular}

For current conditions, groundwater accounts for $13 \%$ of Lake Stockton inputs and outputs. Incident rainfall and evaporation account for the largest input (68\%) and output (87\%) components, respectively. The lake balance with and without mine input is displayed in pie charts below (Figure 9).
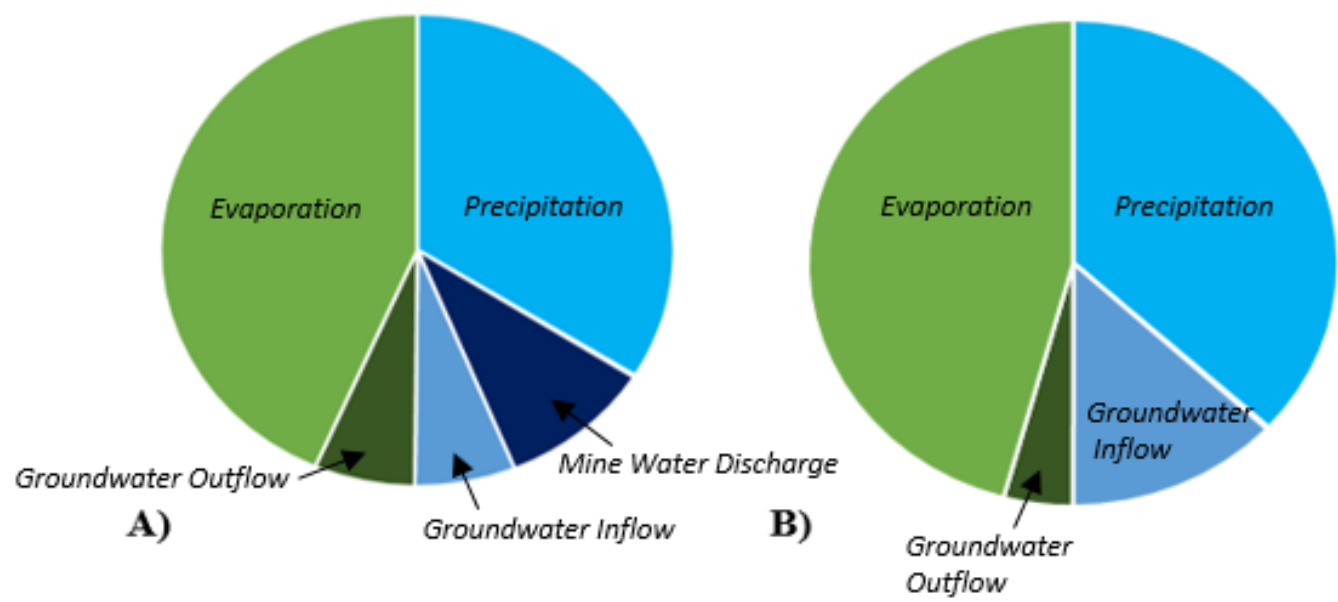

Figure 9 Relative percentages of lake water balance components for steady state conditions (a) current conditions; (b) ceased mine water input 


\subsection{Lake level results}

\subsubsection{Steady state}

The steady state model resulted in a lake stage of $194.3 \mathrm{~m}$ AHD, which compared well with the set initial lake stage of $194.4 \mathrm{~m}$ AHD (average field measured levels for 2016-2017). When mine water was omitted from the lake inputs, the model predicted the lake level to be $190.6 \mathrm{~m}$ AHD in steady state conditions. This represents a $3.7 \mathrm{~m}$ decrease in the initial lake level. The magnitude of water level decline is substantial and highlights the current lake water balance dependence on mine water discharge.

\subsubsection{Transient}

As rainfall and evaporation were identified to be key water balance components, the coupled groundwater-surface water model was run under transient conditions to investigate seasonal variations. Using modelled heads and the simulated lake level from the steady state simulation as the initial conditions, the system was simulated under transient conditions in 12 (monthly) stress periods (360 days). Long-term monthly average precipitation, evaporation, and runoff were input into the model, with storage parameters given in Table 2. Calibrated steady state groundwater heads and lake levels were used as initial conditions. Six time-steps were used with a geometric progression of 1.2 per stress period. Lake levels fluctuated and deviated from the steady state lake level as shown in Figure 10.

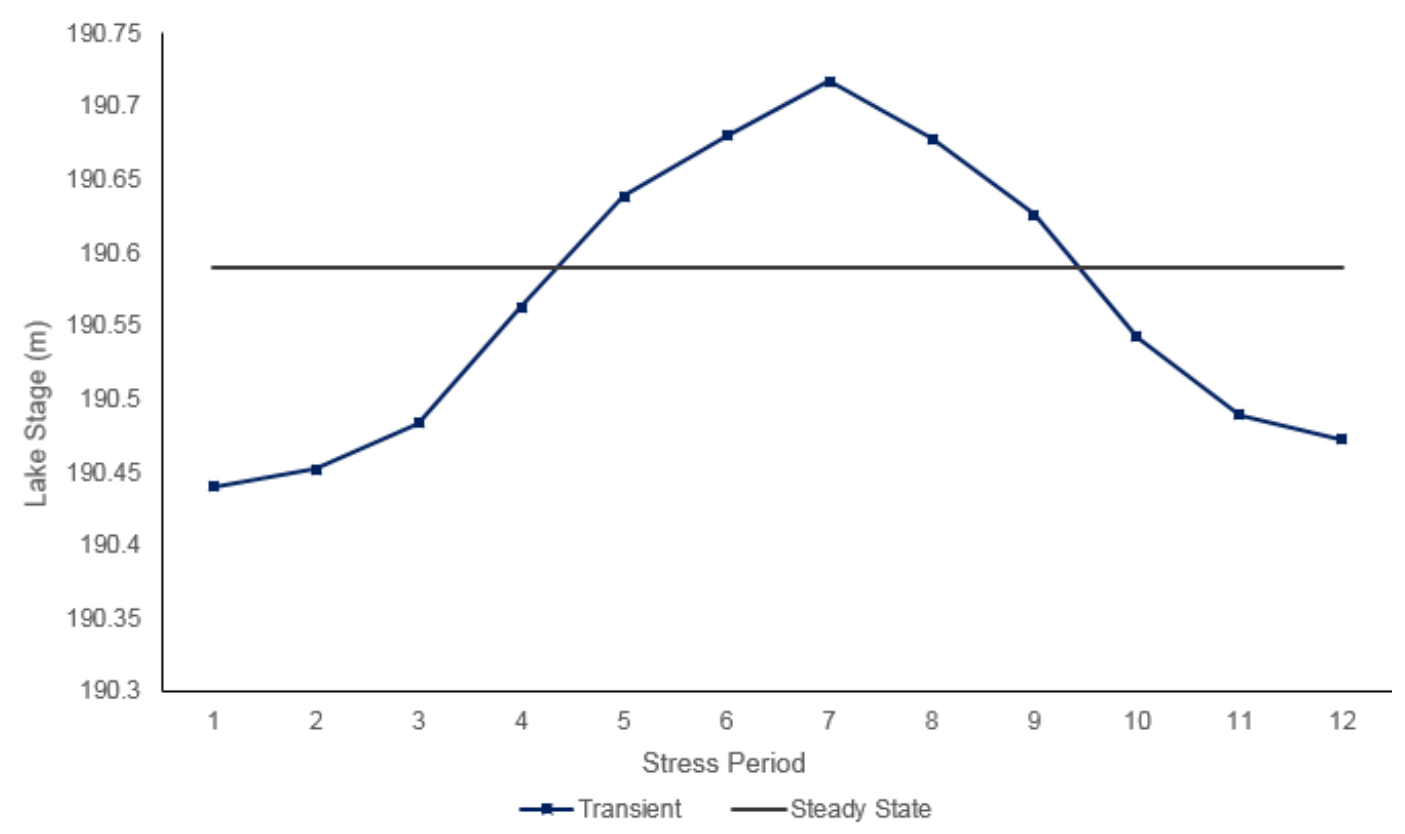

Figure 10 Simulated seasonal lake stage fluctuations for Lake Stockton

Transient simulation suggests lake levels will reach a pseudo-sinusoidal steady state with fluctuations between 190.44 and $190.71 \mathrm{~m}$ AHD. The model forecasts $0.3 \mathrm{~m}$ seasonal variation illustrated in Figure 10. Lake Stockton naturally has up to $1 \mathrm{~m}$ seasonal variations (based on 2016-2017 measured data), whereas the model only accounts for approximately $0.30 \mathrm{~m}$ seasonal variation. This could be attributed from long-term monthly averages in rainfall and evaporation used in the transient simulation, however only two years of lake data was considered. Cheng \& Anderson (1993) observed a similar result and suggested it could possibly be due to the flow system not reaching a dynamic cyclic steady state during the 12 stress periods (Anderson \& Woessner 1992).

Regardless of the seasonal fluctuations, the transient results suggest average lake stage would decline between 3.6 and $3.9 \mathrm{~m}$ from the modelled steady state level. This estimated lake stages from the transient model are very similar to the steady state outcome. The time in which the lake will reach its lower steady state level was not estimated in this study but is likely to be within 10-30 years. 


\subsubsection{Sensitivity analysis}

A sensitivity analysis was conducted post-predictions to assess how specified parameters influenced modelling results. Due to the shorter run time, the sensitivity analysis was undertaken in the steady state model. The main parameters considered were recharge and lakebed conductivity. Model values were doubled and halved to quantify the uncertainty in model predictions. It was expected that the selected magnitude in modification represents the maximum uncertainty in parameter values. It is unlikely model parameters would vary greater than this range as they were based onsite measured parameters quantified in prior studies. Sensitivity was quantified with residuals in water table elevations predicted in the steady state model in monitoring wells used for calibration and the predicted lake stage of $190.6 \mathrm{~m}$ AHD at Lake Stockton. The sensitivity analysis suggested model results could vary by $0.6 \mathrm{~m}$ from the steady state result.

\section{Discussion}

\subsection{Study outcomes}

Summarising the local hydrogeology and physical characteristics of Lake Stockton has not previously been undertaken and this study provides a foundation for future research. As mentioned previously, the Stockton Ridge influences groundwater flow to Lake Stockton (Zhang et al. 2007), although the northern extent of this basement ridge is unknown. Knowledge of its extent would assist in further conceptualising this area. This study highlights the need for further studies to understand the connection between the sub-basins.

Model simulation of the lake level with reduced Ewington discharges should be regarded as semi-quantitative due to inherent uncertainties in input datasets, limitations in transient calibration and in understandings of lake processes, such as climatic interactions and groundwater flow characteristics (Castendyk et al. 2015). Despite this, the coupled groundwater-surface water flow model still allows us to investigate groundwater inflow and how Lake Stockton's levels may change in future, based on the current and estimated future potential lake water balance.

Pit lake modelling for Lake Stockton was impeded by limited available site hydrogeological data and water balance components particularly, lake evaporation rates. To better validate the model and increase its accuracy, ongoing calibration of the model to the current site data would help identify areas in the model that may need improvement. Further investigation on the following would improve model results:

- Hydraulic characteristics of the Nakina Formation aquifer.

- Limited monitoring well data for calibration to the east of Lake Stockton.

- Thickness and conductivity of lakebed sediments.

- Further investigation on the influence of surface runoff on lake results.

- Extent, direction, and conductivity of underground workings.

- Account for a decrease in winter rainfall and catchment runoff from a drying climate, which is likely to be significant.

This study suggests that longer term impacts of non-supply may reduce lake water levels by about $3.7 \mathrm{~m}$. A sensitivity analysis indicated that lake stage predictions are sensitive to model parameters, however, within the likely parameter ranges, the decline in the lake level is expected to be at least $3 \mathrm{~m}$ or greater than $4 \mathrm{~m}$.

\subsection{Future management options for Lake Stockton}

There is limited literature on the suitability of pit lake water depth and safe access for recreational use as pit lakes are often reviewed on a case-to-case basis and pit lake water quality is often a greater concern for recreational lakes. Pit lakes are also often large and deep enough that the pit lake is clearly suitable for recreation. However, Lake Stockton is relatively shallow compared to other pit lakes. The future declining 
water level will further expose steep pit walls, creating abrupt drop off points and limited shallow margins, increasing the risk for physical injuries, potential falls, or drownings and need to be rehabilitated to enable safe recreational use (McCullough et al. 2009, 2018; Hinwood et al. 2012). The exposed sandstone material of the pit walls is strong and a fall in water level of $3-4 \mathrm{~m}$ is understood to be unlikely to significantly alter the geotechnical integrity of the high walls.

Where steep pit walls are exposed, it is suggested public access to be obstructed or appropriate rehabilitation to be undertaken. Safe areas for access to the lake should be identified or created if the recreational use is to be continued.

There is currently no minimum water depth requirement for recreational boating or water skiing specifically for pit lakes. Nevertheless, Collie Basin pit lakes are considered navigable waters under the Navigable Water Regulations 1958 (NWR) (Government of Western Australia 1958) as they are waters within Western Australia where a vessel or marine craft can be navigated. According to Regulation 48 of the NWR, "a person shall not, in any navigable waters, drive a motor boat at a speed exceeding 8 knots, water ski or para-sail in any water with a depth of less than 3 metres; or within 50 metres of the water's edge".

Based on the criteria for recreation in Western Australia navigable waters, the predicted decline in water level will still provide some area required for recreation. The predicted water level after dewatering cessation and the suitable recreational area that meets regulation is illustrated in Figure 11. The suitable recreational area would reduce based on the minimum depth criteria of $<3 \mathrm{~m}$ and a $50 \mathrm{~m}$ cut-off distance to the pit walls. The recreational area would be reduced by $17 \%$ with an area loss of $11,580 \mathrm{~m}^{2}$ and approximately 2-30 m around the recreation area perimeter. Potentially, these deeper areas could be marked with, for example, buoys as a guide for users to delineate the allowable skiing area.

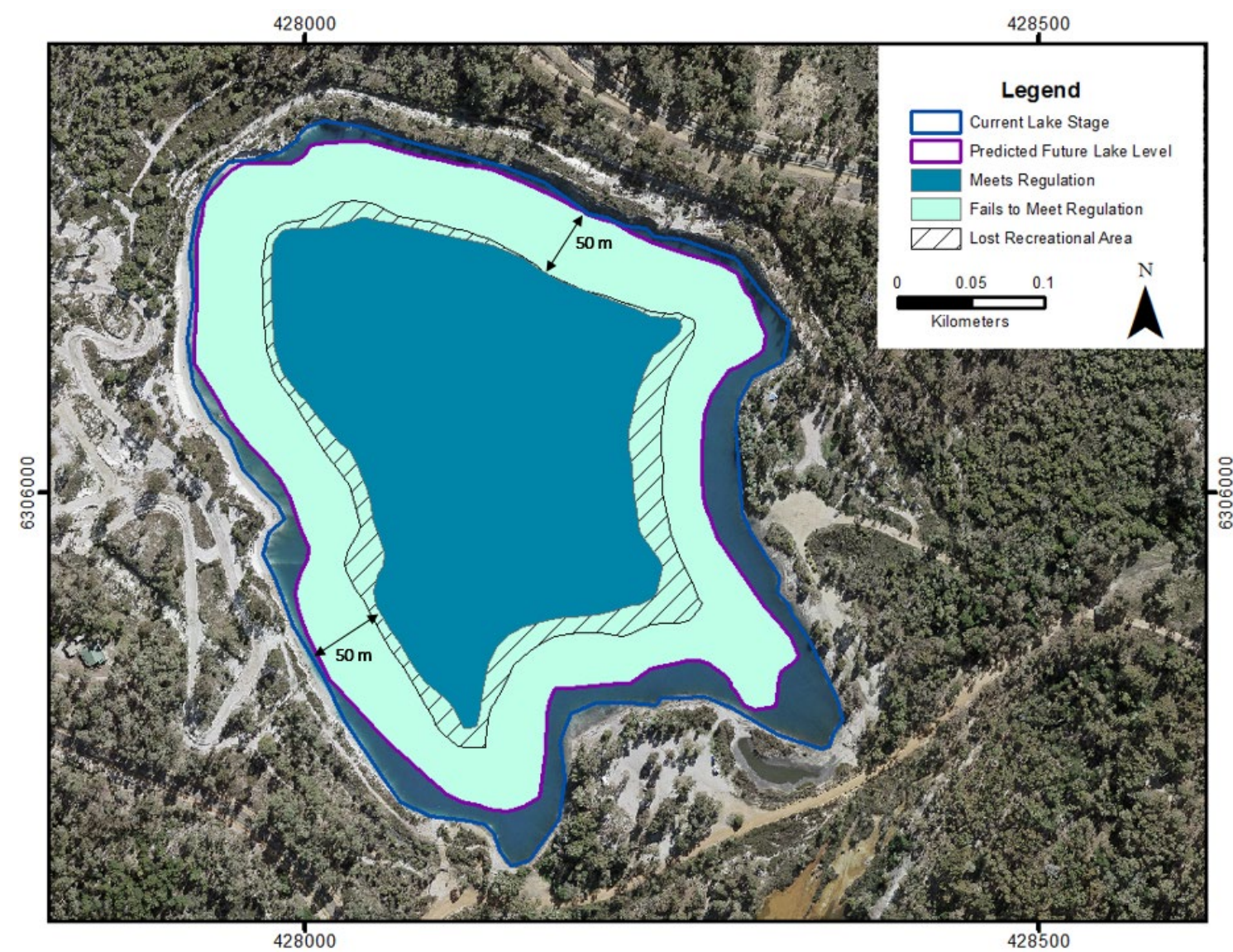

Figure 11 Predicted lake level of Lake Stockton and suitable recreational area following dewatering cessation [Coordinate system: GDA 1994 MGA Zone 50; Aerial Imagery (c) Metro Smartsheet 2009] 


\section{Conclusion}

Maintaining the recreational functionality of Lake Stockton is expected to continue to provide benefits for the Collie community (McCullough et al. 2009). Providing space for active and passive recreation provides growth for communities in regional areas and assists small towns to survive economically when mining ends. These benefits rely on a certain degree of ongoing lake management to minimise exposure to steep lake walls and the potential for physical injuries.

The methodology employed in this study can be applied to other pit lakes in the Collie Basin, given that the coupled model allows investigation of the impact of groundwater-surface water interaction on lake water balance despite limited data available.

\section{Acknowledgement}

We acknowledge the support of Griffin Coal for this project, in particular the support from Paul Irving.

\section{References}

Anderson, MP, Hunt, RJ, Krohelski, JT \& Chung, K 2002, 'Using high hydraulic conductivity nodes to simulate seepage lakes', Ground Water, vol. 40, pp. 117-122.

Anderson, MP \& Woessner, WW 1992, Applied groundwater modeling: simulation of flow and advective transport, Academic Press, San Diego.

Balistrieri, LS, Tempel, R, Stillings, LL \& Shevenell, LA 2006, 'Modeling spatial and temporal variations in temperature and salinity during stratification and overturn in Dexter Pit Lake, Tuscarora, Nevada, USA', Geochem, vol. 21, pp. 1184-1203

Castendyk, D, Eary, LE \& Balistrieri, LS 2015, 'Modeling and management of pit lake water chemistry 1: Theory', Applied Geochemistry, vol. 57, pp. 267-288.

Castro, JM \& Moore, JN 2000, 'Pit lakes: their characteristics and the potential for their remediation', Environmental Geology, vol. 39, pp. 254-260.

Cheng, X \& Anderson, MP 1993, 'Numerical simulation of ground-water interaction with lakes allowing for fluctuating lake levels', Ground Water, vol. 31, pp. 929-933.

Commander, DP, Mills, CH \& Waterhouse, JD 1994, 'Salinisation of mined out pits in Western Australia', Proceedings of the XXIV Congress of the International Association of Hydrogeologists, International Association of Hydrogeologists, Adelaide, pp. 527-532.

Council, GW 1997, 'Simulating lake-groundwater interaction with mudflow, 1997 Georgia Water Resources Conference, The University of Georgia, Athens, pp. 457-462.

Environmental Simulations Incorporated 2000, Groundwater Vistas, version 6, computer software, Environmental Simulations Incorporated, Leesport.

Fetter, CW 1994, Applied Hydrogeology, 3rd edn, University of Wisconsin, Oshkosh.

Government of Western Australia 1958, Navigable Waters Regulation 1958, pp. 622-632.

Hammond, G \& Boyd, G 1988, 'Dewatering at Western No. 7 Colliery', Proceedings of the $3^{\text {rd }}$ International Mine Water Congress, International Mine Water Association, Melbourne, pp. 733-741.

Hanna, TM, Elfadil, AA \& Atkinson, LC 1994, 'Use of an analytical solution for preliminary estimates of ground water inflow to a pit', Mining Engineering, vol. 46, pp 149-152.

Hinwood, A, Heyworth, J, Tanner, H \& McCullough, CD 2012, 'Recreational use of acidic pit lakes - human health considerations for post closure planning', Journal of Water Resource and Protection, vol. 4, pp. 1061-1070.

Hunt, RJ, Anderson, MP \& Kelson, VA 1998, 'Improving a complex finite difference ground water-flow model through the use of an analytic element screening model', Ground Water, vol. 36, pp. 1011-1017.

Hunt, RJ, Haitjema, HM, Krohelski, JT \& Feinstein, DT 2003, 'Simulating ground water-lake interactions: approaches and insights', Ground Water, vol. 41, pp. 227-237.

Le Blanc Smith, G 1993, 'The geology and Permian coal resources of the Collie Basin, Western Australia', Western Australian Geological Survey Report 38, p. 86.

Lee, TM 1996, 'Hydrogeologic controls on the groundwater interactions with an acidic lake in karst terrain, Lake Barco, Florida', Water Resources Research, vol. 32, pp. 831-844.

Luke, GJ, Burke, KL \& O’Brien, TM 1987, 'Evaporation data for Western Australia', Resource Management Technical Report Department of Agriculture, Perth.

Lund, M, Bills, D, Keneally, T, Brown, S \& Thompson, S 2000, 'Bacterial strategies for increasing pH in acidic voids', Final void water quality enhancement: Stage III, ACARP Project Number C8031 report, Perth, pp.169-222.

Lund, MA, McCullough, CD \& Radhakrishnan, NK 2012, 'The Collie Pit Lake District, Western Australia: an overview', Proceedings of the International Mine Water Association Symposium, Mine Water and Environment Research Centre, Bunbury, pp. 287-294. 
McCullough, CD, Hunt, D \& Evans, LH 2009, 'Sustainable development of open pit mines: creating beneficial end uses for pit lakes', in D Castendyk \& T Eary (eds), Mine Pit Lakes: Characteristics, Predictive Modeling, and Sustainability Society for Mining, Metallurgy, and Exploration (SME), Colorado.

McCullough, CD \& Lund, MA 2006, 'Opportunities for sustainable mining pit lakes in Australia', Mine Water and the Environment, vol. 25, pp. 220-226.

McCullough, CD, Marchand, G \& Unseld, J 2013, 'Mine closure of pit lakes as terminal sinks: best available practice when options are limited?', Mine Water and the Environment, vol. 32, pp. 302-313.

McCullough, CD, Müller, M, Eulitz, K \& Lund, MA 2011, 'Modelling a pit lake district to plan for abstraction regime changes', AB Fourie, M Tibbett \& A Beersing (eds), Proceedings of the Sixth International Conference on Mine Closure, Australian Centre for Geomechanics, Perth, pp. 581-592.

McCullough, CD, Schultze, M \& Vandenberg, J 2018, 'Realising beneficial end uses for pit lakes', in C Drebenstedt, F von Bismarck, A Fourie \& M Tibbett (eds), Proceedings of the 12th International Conference on Mine Closure, TU Bergakademie, Leipzig, pp. 497-504.

Merrit, ML \& Konikow, LF 2000, Documentation of a Computer Program to Simulate Lake-aquifer Interaction Using the MODFLOW ground-water flow model and the MOC3D solute transport model, United States Geological Survey, Reston, p. 4167.

Moncrieff, JS 1993, 'Hydrogeology of the Collie Basin, Western Australia', Western Australia Geological Survey, pp. 129-153.

Müller, M, Eulitz, K, McCullough, CD \& Lund, MA 2010, Mine Voids Management Strategy (V): Water Quality Modelling of Collie Basin Pit Lakes, Edith Cowan University, Perth, p. 105.

Niccoli, WL 2009, 'Hydrologic characteristics and classifications of pit lakes', in D Castendyk \& T Eary (eds), Mine Pit Lakes: Characteristics, Predictive Modeling, and Sustainability, Society for Mining, Metallurgy, and Exploration, Colorado.

Schultze, M, Hemm, M, Geller, W \& Benthaus, F-C 2013, 'Pit lakes in Germany: Hydrography, water chemistry and management', in W Geller; M Schultze; R L P Kleinmann \& C Wolkersdorfer (eds), Acidic Pit Lakes - Legacies of surface mining on coal and metal ores, Springer, Berlin.

Stedman, C 1988, 100 Years of Collie Coal, Curtin Printing Services, Perth, p. 363.

Varma, S 2002, Hydrogeology and Groundwater Resources of the Collie Basin, Western Australia, Hydrogeological Record Series HG 5 , by Water and Rivers Commission, Perth, p. 80.

Wilson, AC 1990, 'Collie Basin', Geology and Mineral Resources of Western Australia, Memoir 3, Geological Survey of Western Australia, Perth.

Zhang, Q, Varma, S, Bradley, J \& Schaeffer, J 2007, Groundwater Model of the Collie Basin, Western Australia, Department of Water, Government of Western Australia, Perth, p. 106. 
